\title{
5
}

\section{Expressions of Indigenous rights and self-determination from the ground up: A Yawuru example}

\author{
Mandy Yap and Eunice Yu
}

\section{Introduction}

While recognition is one way self-determination for indigenous peoples can be enacted, the processes and models of recognition are fraught and complicated (Coulthard 2014). Additionally, the act and process of recognition for indigenous peoples tends to occur within existing dominant Western frameworks and is imbued in power relations; therefore, the extent to which recognition may effectively address the issues of structural injustice remains questionable (Fraser \& Honneth 2003, Andersen 2014, Coulthard 2014). One of the challenges in enabling self-determination for Australia's Indigenous peoples stems from the increasing influence of neoliberalism in Indigenous policy (Altman 2007, Humpage 2008, Howard-Wagner 2010).

The prevalence of neoliberalism in academic and policy discourse is evident from the increasing amount of scholarly writing on the topic (Peck \& Tickell 2002, Humpage 2008, Boas \& Gans-Morse 2009, Venugopal 2015). Boas and Gans-Morse (2009: 143-45) offer four approaches in which neoliberalism has been used in the literature, including to examine economic reform policies, as a development 
model, to denote an ideology and to characterise an academic paradigm. Notwithstanding how neoliberalism has been operationalised within the different approaches, the case in point is the permeation of key values, ideals and norms associated with neoliberalism into the social, economic and political sphere. In this section, fellow contributors offer examples of how legislation provisions in Australia are imbued in principles and values of neoliberalism, arguing that neoliberalism as a guiding philosophy of Indigenous policy undermines Indigenous self-determination. The spread of neoliberalism in indigenous policy is also evident in New Zealand and Canada (see Humpage, O'Sullivan and Altamirano-Jiménez, this volume).

Policies aimed at improving Indigenous wellbeing in Australia through the monitoring of Indigenous socio-economic outcomes according to specific ideals and values from the dominant society can be seen as an extension of neoliberalism. The governing, measurement and evaluation of all domains of society according to a set of principles associated with the market results in benchmarking of society against an idealised vision of a 'good market', which includes a good job, healthy lifestyles and consumer rationality (Mirowski 2009, Davies 2015: 301). Yet, these idealised visions do not reflect notions of wellbeing for Indigenous peoples.

\section{Aspects of wellbeing for many Indigenous peoples}

The literature on Indigenous wellbeing points to wellbeing as both a process and outcome, that is achieved and maintained as a collective and relationally. Furthermore, the literature reveals the importance of maintaining connection to country and culture and self-determination over matters concerning one's self, one's family, community and country (Greiner et al. 2005, Durie 2006, Grieves 2007, Panzironi 2007, Ganesharajah 2009, Yu 2012, McCubbin et al. 2013, Murphy 2014).

Indigenous worldviews and values can and should provide an alternative foundation to understanding rights and self-determination for Indigenous peoples. This alternative set of values requires the direct inclusion of Indigenous voices and requires engagement with Indigenous peoples' historical experience of colonisation (Watene 2016). This chapter offers a broader perspective of rights and self-determination through working with the Yawuru community in Broome to model co-production of 
knowledge from the ground up. This model has its foundation in Yawuru worldviews, privileges Yawuru voices and starts with mabu liyan, Yawuru's philosophy for living well. Through a participatory mixed methods approach, the findings will illustrate that self-determination for the Yawuru is both an aspect of mabu liyan and also a pathway towards achieving and sustaining mabu liyan.

\section{Indigenous peoples and self-determination}

Self-determination is a basic human right that also carries instrumental value for individual wellbeing (Sen 1999, Webb 2012). Perhaps unsurprisingly, the principles of self-determination underpin the United Nations Declaration of the Rights of Indigenous Peoples (UNDRIP), an international standard-setting mechanism to support indigenous peoples' rights to a development paradigm that reflects their collective sense of identity, built on the strength of their culture and identity and in balance with the environment. ${ }^{1}$

The principles of and rights to self-determination for indigenous peoples have been discussed at length within the legal and political space in Australia and internationally (Panzironi 2007). At these levels, rights and recognition for indigenous peoples may come in the form of indigenous representation or allocated seats at the table, such as the dedicated Māori seats in the New Zealand Parliament or the Sami Assembly. In Australia, representative bodies of Indigenous peoples such as the former Aboriginal and Torres Strait Islander Commission and, more recently, the National Congress of Australia's First Peoples are important vehicles for Indigenous Australians.

However, the claims and expressions to self-determination may extend beyond these domains (Panzironi 2007). Watene (2016) and Davis (2013) argue that, to fully capture self-determination, engagement with Indigenous peoples and communities about their perspectives on self-determination are necessary. This chapter echoes the sentiment of both scholars and argues that to fully understand self-determination,

1 For the full text of the United Nations Declaration of the Rights of Indigenous Peoples, see www.un.org/development/desa/indigenouspeoples/declaration-on-the-rights-of-indigenous-peoples. html. 
an important starting point is for Indigenous communities to express what constitutes a life where Indigenous peoples are able to pursue their economic, political and cultural rights as set out in UNDRIP.

In the 1970s, self-determination for Indigenous Australians was proposed as the guiding principle for Indigenous affairs following a period of paternalistic policies of assimilation (HREOC 2002). Land rights legislation, native title and the emergence of an Indigenous sector signalled a promising shift towards self-determination for Indigenous Australians (HREOC 2002, Sanders 2002, Rowse 2012). That promise, however, was short-lived, with the introduction of policies such as the Northern Territory Emergency Response affecting any progress towards Indigenous control over matters concerning their lives (Altman \& Hinkson 2010).

The ambiguities surrounding what it means to be self-determining within the legal and political context has challenged the implementation of policies that truly facilitate self-determination of indigenous communities (Sanders 2002, Anaya 2004, Webb 2012). For many indigenous peoples, self-determination is fundamentally about the right and freedom to live the life they value, and to participate in the process of decisionmaking concerning them (Daes 2000). As the Human Rights and Equal Opportunity Commission (HREOC) notes, 'self-determination as the centre piece of Indigenous policy has to a large extent been a statement of intention rather than of action. Real self-determination has never been tried' (HREOC 2002: 3).

\section{Indigenous wellbeing and the politics of recognition in Australia}

Despite the continuous call by Indigenous Australians to have the rights to set their own development agenda, the policies pertaining to them in the last decade have focused on achieving statistical equality with their non-Indigenous counterparts to improve their wellbeing (Taylor 2008, Jordan et al. 2010, Kukutai \& Walter 2015). As a result, much of the research and data collection efforts at informing the evidence base tend to focus on government programs designed to reduce disadvantage faced by Indigenous Australians. What is 'recognised' as evidence is often considered synonymous with official data collected and analysed for the purposes of informing government reporting (Taylor 2008, Kukutai \& 
Walter 2015). Such research often uses a top-down approach, and may be expertly driven or derived with very little input from communities or from the peoples who are the beneficiaries of government policies and programs.

The tension that exists between the worldviews of indigenous peoples and government reporting frameworks is what Taylor has termed 'the recognition or translation space' (Taylor 2008). It is this area of intersection between the two spaces where meaningful and substantive engagement and measurement is necessary (Taylor 2008). More importantly, 'recognition' is a vital human need, and misrecognition can be seen as another form of oppression (Taylor 1992: 25).

The 'recognition space' is where two or more forms of law, knowledge, culture and worldview encounter or intersect (Pearson 1997, Mantziaris \& Martin 2000, Ermine 2007, Taylor 2008). In essence, most authors describe 'the space' as a means through which Indigenous worldviews and aspirations can become 'recognised' within the broader political, legal and statistical reporting frameworks. Kukutai and Walter (2015) further offer five recognition principles to increase information functionality for Indigenous peoples: recognising cultural diversity, recognising geographical diversity, recognising different ways of knowing indigenous peoples, mutual capacity-building and indigenous decision-making. These five principles are important in the process of operationalising the 'recognition space' to elicit indigenous articulations of self-determination and to challenge the normative definitions of selfdetermination.

\section{Self-determination on the ground}

What self-determination might mean within the lived experiences, strengths and challenges faced by Australian Indigenous communities on the ground has remain largely unexplored amid the large body of literature on self-determination (Behrendt 2002, Davis 2013, Watene 2016). Indigenous and non-Indigenous scholars have argued that the concept of self-determination needs to be understood and expressed within an alternative framework that recognises relational aspects of selfdetermination, in particular relating to the natural world, to the collective and to sustainability (Behrendt 2002, Anaya 2004, Corntassel 2008, Coulthard 2014, Murphy 2014). 
The former Chair of the United Nations Working Group on Indigenous Populations, Professor Erica-Irene Daes, offered the following definition of self-determination:

Self-determination means the freedom for indigenous peoples to live well, to live according to their own values and beliefs, and to be respected by their non-indigenous neighbours ...

the true test of self-determination is not whether indigenous peoples have their own institutions, legislative authorities, laws, police and judges. The true test of self-determination is whether indigenous peoples themselves actually feel that they have choices about their way of life. (Daes 2000: $\mathrm{x}$ )

This suggests that the starting point surely is to first understand what it means to live well for indigenous peoples according to their own values and beliefs. For the Yawuru that is mabu liyan.

Mabu liyan (good liyan) reflects Yawuru's sense of belonging and being, emotional strength, dignity and pride. Expressions of liyan are articulated based on collective structures: it is a model of living well in connection with country, culture, others and with oneself (McKenna \& Anderson 2011, Yap \& Yu 2016a). Starting with mabu liyan as the central focus of Yawuru wellbeing is recognising that there is a different way of understanding what wellbeing is, and how rights and self-determination might operate within the philosophy of mabu liyan.

\section{Yawuru rights and responsibilities - standing in two worlds}

The Yawuru people are the traditional owners of the lands and waters in and around Rubibi (the town of Broome) from Bangarangara to the yalimban (south) to Wirrjinmirr (Willie Creek) to the guniyan (north), and banu (east) covering Roebuck Plains and Thangoo pastoral leases, in the Kimberley region of northern Western Australia (Yawuru RNTBC 2011).

In 2010, after 20 long years, the Yawuru secured native title, recognising Yawuru's enduring relationship with their land. The Native Title Determination has provided Yawuru with the opportunity to have a say over the land and its usages and to have an input into issues affecting Yawuru in local and regional settings (Yawuru RNTBC 2011). Within the Western and political legal frameworks, the Yawuru have to consider how 
their rights and entitlements can be exercised and negotiated. However, for the Yawuru, there is a set of cultural rights and responsibilities that arise from the bugarrigarra, ${ }^{2}$ the core of Yawuru cosmology. Self-determination, for Yawuru, cannot be disconnected from the broader rights and responsibilities of looking after country and fulfilling one's cultural obligations as Yawuru.

\section{The Yawuru Wellbeing Project-exercising self-determination in the 'recognition space'}

The importance of self-determination and autonomy is critical within a research paradigm to ensure that power relations are transformed, whereby Indigenous peoples as holders of knowledge, expert on their own lives, meaningfully participate in the process to co-produce knowledge as collaborators and partners, not as research subjects or participants (Yap \& $\mathrm{Yu}$ 2016a). In operationalising the 'recognition space' to understand what constitutes wellbeing for the Yawuru, rights and self-determination are exercised in two stages. First, in the process aspect, whereby Yawuru are co-producers of knowledge to conceptualise what rights, recognition and wellbeing means for Yawuru. Second, through the grounding of rights, recognition and self-determination measures informed through narratives by Yawuru women and men. Together, they seek to reveal understandings of living well through Yawuru's worldviews into the recognition space.

\section{Yawuru's participation - a necessary and critical element}

Working with the Yawuru as a distinct language group is recognising that there is geographical and cultural diversity within Indigenous Australians as a collective. Yawuru's participation in the Yawuru Wellbeing Project research ${ }^{3}$ was critical, and thus interwoven throughout the process,

2 Bugarrigarra is the time before time, when the creative forces shaped and gave meaning and form to the landscape, putting the languages to the people within those landscapes and creating the protocol and laws for living within this environment (Yawuru RNTBC 2011: 13).

3 The Yawuru Wellbeing Project combined stories of Yawuru women and men with findings from the Yawuru Wellbeing Survey to paint a localised and multi-dimensional picture of wellbeing. The project aimed to provide a baseline for Yawuru people as a collective to plan and design programs around what might bring about improvements in wellbeing. Please see www.healthinfonet.ecu.edu. au/key-resources/programs-projects?pid=3245. 
from research content to survey design and collection, to ensure that understandings about self-determination from the ground up are privileged (Behrendt 2002, Watene 2016, Yap \& Yu 2016b).

The various ways in which Yawuru's worldviews, aspirations and participation has been prioritised in this research has been outlined elsewhere (Yap \& Yu 2016a). As a first step, Yawuru's own agenda to measure wellbeing according to their worldviews, together with a $\mathrm{PhD}$ research proposal by a non-Indigenous student, which aimed to develop culturally relevant measures of wellbeing, provided a common group for forming a collaborative partnership between this chapter's two authors (Yap \& Yu 2016a). The setting up of the Yawuru Guidance and Reference Committee ensured that the information generated through the research reflected local aspirations and values and, most importantly, was functional for Yawuru needs. Yawuru's participation in the research was critically interwoven throughout the process, from research content to survey collection, to ensure Indigenous decision-making as a principle was operationalised in the recognition space.

Mutual capacity building is a necessary element in enabling selfdeterminations. The employment of 10 local research assistants and purchase of iPads facilitated through Bankwest Curtin Economics Centre enabled this. The mutual capacity building built into the research with Yawuru women and men further ensured that knowledge is co-produced from the ground up, bringing together different ways of knowing, both traditional and Western, in a manner that is consistent with the recognition space.

\section{Conceptions of rights, recognition and self-determination by Yawuru}

\section{From stories to indicators to measures}

Underpinning Yawuru's wellbeing is the notion of liyan. There was general consensus from Yawuru women and men that liyan is a feeling, not just in one sense but all senses. Yawuru derive mabu liyan from touching, eating, feeling, being and doing. Liyan is also about how one relates to others, to the surroundings, and to the environment. As a result, values that bring about the maintenance of good relations with others and one's 
surroundings were important as a Yawuru philosophy of being. There were several key themes arising from what brings about mabu liyan for Yawuru. They include family, connection to country and culture, standard of living, health, safety and respect, community, and rights and recognition. This chapter will not reproduce all the themes outlined in previous publications (see Yap \& Yu 2016a, 2016b). Instead, it will focus on expressions and conceptions of rights, recognition and self-determination for Yawuru.

These concepts of rights and recognition critically laid the foundation for the grounding of indicators and survey questions according to Yawuru's worldviews. The grounding of the indicators from the stories by Yawuru women and men further created a sense of 'ownership' in the operation of the 'recognition space' and allow for further expressions of selfdetermination by Yawuru (see Table 5.1).

Table 5.1: The development of indicators of rights of recognition for Yawuru

\begin{tabular}{|c|c|c|c|c|}
\hline Themes & $\begin{array}{l}\text { Examples of } \\
\text { interview }\end{array}$ & Indicators & $\begin{array}{l}\text { Selected/not } \\
\text { selected by } \\
\text { focus groups }\end{array}$ & $\begin{array}{l}\text { Translated to } \\
\text { survey question }\end{array}$ \\
\hline \multirow[t]{2}{*}{$\begin{array}{l}\text { Rights and } \\
\text { recognition }\end{array}$} & $\begin{array}{l}\text { 'Being respected by } \\
\text { other people, both } \\
\text { Aboriginal and non- } \\
\text { Aboriginal is a part of } \\
\text { self-determination' }\end{array}$ & $\begin{array}{l}\text { Feel } \\
\text { respected by } \\
\text { Indigenous } \\
\text { and non- } \\
\text { Indigenous } \\
\text { people in my } \\
\text { community }\end{array}$ & $\begin{array}{l}\text { Picked by } \\
\text { Yawuru } \\
\text { women } \\
\text { Picked by } \\
\text { Yawuru men }\end{array}$ & $\begin{array}{l}\text { I felt respected and } \\
\text { my opinions valued } \\
\text { most or all of the } \\
\text { time }\end{array}$ \\
\hline & $\begin{array}{l}\text { 'We need to keep } \\
\text { the seasons going } \\
\text { by looking after } \\
\text { the country as } \\
\text { best we can by } \\
\text { communicating it and } \\
\text { sharing it with others } \\
\text { so that they can } \\
\text { understand as well } \\
\text { why it is important, } \\
\text { why we need access } \\
\text { to those parts of } \\
\text { country' }\end{array}$ & $\begin{array}{l}\text { Sharing } \\
\text { Yawuru } \\
\text { culture with } \\
\text { Indigenous } \\
\text { and non- } \\
\text { Indigenous } \\
\text { peoples }\end{array}$ & $\begin{array}{l}\text { Picked by } \\
\text { Yawuru } \\
\text { women } \\
\text { Picked by } \\
\text { Yawuru men }\end{array}$ & $\begin{array}{l}\text { In the last } \\
12 \text { months, did } \\
\text { you share Yawuru } \\
\text { culture with } \\
\text { Indigenous and } \\
\text { non-Indigenous } \\
\text { peoples? } \\
\text { (E.g. have a } \\
\text { yarn, cultural } \\
\text { tour, welcome } \\
\text { to country) }\end{array}$ \\
\hline
\end{tabular}

Source: Adapted from Yap (2017) and Yap \& Yu (2016b). 


\section{Rights and respect}

Having human rights is fundamental to Yawuru's sense of wellbeing. These include having basic human rights, feeling respected, having autonomy and control and being free from discrimination.

Having human rights is fundamental for wellbeing. Rights that were denied to our grandparents. We have some so far since then and there is still room for improvement (Yawuru female, 34 years old). ${ }^{4}$

For many Indigenous peoples, the right to maintain one's distinct cultural identity is a fundamental human right. For the Yawuru, an aspect of this is speaking the Yawuru language.

Language is the basis of identity, the basis of confidence and culture ... We need to keep our language strong and reinvigorate it for us who were not able to learn it properly as kids for whatever reason. We shouldn't feel ashamed of that. We need to say to our people that-It is okay that we didn't learn to speak our language properly. It was a time when we were not allowed to speak our language, where it was great pressure on us to not speak our language. That shouldn't stop us from learning our language or teaching our children language (Yawuru male, 58 years old).

The narrative above suggests that Yawuru people, like many other Indigenous language groups, did not have the opportunity to learn or were not permitted to speak their Indigenous language growing up. As a result, the number of Yawuru speakers declined to a critical level. The language efforts driven by Yawuru through the establishment of the Yawuru Language Centre alongside the concerted effort towards building a cohort of Yawuru speakers and teachers has led to a revitalisation of the Yawuru language.

Respect is an important element of Yawuru conceptions of selfdetermination and wellbeing. This includes showing respect towards others and also being respected by others. Feeling free from discrimination is also critically important for self-determination. As one woman describes:

Being respected by other people, both Aboriginal and non-Aboriginal is a part of self-determination. Getting rid of racism is part of selfdetermination (Yawuru female, 34 years old).

4 All quotes taken from participants in the Yawuru Wellbeing Project except where otherwise specified. 
For Yawuru, the importance of being traditional owners and the responsibility over traditional country is another dimension of respect for territory, respect for country and respect for other Aboriginal groups' connections to their land, and the need for others to respect Yawuru's responsibility for their traditional country.

Respect should be handed down and respect is involved with culture, family and kinship. The land provides for you, so you respect the land because it looks after you. Country will look after you if you look after country. I am not just talking about Yawuru country, I am talking about every part of Australia. Where ever I go to someone else's country, I will respect the land because one, it is not mine and two because its's the black fella way (Yawuru male, 30 years old).

\section{Connectedness to country and culture}

Not dissimilar to other indigenous groups around the world, the Yawuru people describe a deep physical, cultural and spiritual connection to their country in which they live but also identify with. Knowing about land and sea, hunting and fishing, eating bush tucker and seasonal catch, spending time with elders, sharing and receiving of catch and kill are all dimensions of connection to culture and country for Yawuru women and men.

As a result, management of country and culture is a responsibility and right which arises through Yawuru's intrinsic connection to the land, both physically, emotionally and spiritually:

not only the trees provide us with the tools, medicine, food, but the connection to that biodiversity, the birds everything that utilise the area ... lizards ... when you start to draw the picture. People start to see it's not just a piece of rubbish, desolate savannah ... these are the animals, reptiles and things that reside here $\ldots$ and when you give it cultural significance, you give it a living landscape ... Yawuru people and the land are intrinsically connected ... and wellbeing are intrinsically connected. Anything done to the land, it's like hurting them because of the connection to land (Yawuru male, 41 years old).

The ability to exercise rights and self-determination to maintain a healthy country and fulfil one's cultural obligation is dependent on a range of factors, one of which is access to country:

Once upon a time we used to have access to go down to the beach to our favourite fishing grounds or camping grounds. But you can't do it anymore. It is blocked off. They put fences up to block you off ... We are 
Yawuru people, saltwater people. We have fished in this area for hundreds of years. They come along and tell you that you are not allowed to throw your net there ... (Yawuru female, 70 years old)

However, many individuals further noted that if they had some say or control over what is happening, that may go some way to negating the impacts on their wellbeing.

How do we develop or negotiate or implement programs to make us feel like we can feed that liyan feeling. If we are worried about it ... Implement the program - water monitoring or strategy where ranger group helps inform the mining company. How do we develop a spin off to try and have control over the process (Yawuru male, 41 years old).

While there are the more formal ways of contributing to the management of country and culture through attendance at meetings and representations in programs, an important way in which Yawuru exercise control over and maintains their connection to country and culture is through the sharing of Yawuru culture with other Indigenous and non-Indigenous groups.

We need to keep the seasons going by looking after the country as best we can by communicating it and sharing it with others so that they can understand as well why it is important, why we need access to those parts of country (Yawuru male, 52 years old).

Table 5.2: Expressions of self-determination by Yawuru women and men

\begin{tabular}{|l|r|r|}
\hline Indicators of self-determination for the Yawuru & $\begin{array}{c}\text { Females } \\
\text { (\%) }\end{array}$ & $\begin{array}{c}\text { Males } \\
\text { (\%) }\end{array}$ \\
\hline Felt respected and opinions valued most or all of the time & 51.0 & 63.6 \\
\hline Felt vulnerable to being discriminated against none or little of the time & 74.4 & 76.4 \\
\hline Having total/quite a lot of control over what happens on my country & 18.4 & 19.3 \\
\hline Having total/quite or a lot of control over what happens to my family & 50.0 & 42.9 \\
\hline Having total/quite or a lot of control over what happens to me & 90.8 & 82.8 \\
\hline Attended community meetings & 39.8 & 46.6 \\
\hline Attended community rally/call for action & 33.7 & 31.0 \\
\hline Voted at Yawuru meetings & 31.6 & 36.2 \\
\hline Voted at state/national elections & 48.0 & 46.6 \\
\hline Shared Yawuru culture with Indigenous and non-Indigenous people & 48.0 & 56.9 \\
\hline Feel able to access country to hunt and fish & 80.6 & 79.3 \\
\hline Feel able to access country to practice traditional culture & 62.2 & 69.0 \\
\hline
\end{tabular}

Source: Yawuru Wellbeing Survey 2015. See Yap (2017) and Yap \& Yu (2016a, 2016b). 
Table 5.2 provides some indicators of self-determination as expressed by Yawuru. It is evident that the majority of Yawuru women and men felt they were vulnerable to being discriminated against none or a little of the time. However, a lower share of the population felt respected by others and felt their opinions were valued most or all of the time.

Around a third of Yawuru women and men reported having voted at Yawuru meetings on matters concerning Yawuru, but as high as 57 per cent of Yawuru men reported having shared Yawuru culture with Indigenous and non-Indigenous peoples in the last 12 months. This suggests there is a need to facilitate a broader understanding of expressions of selfdetermination.

\section{Conclusion}

Self-determination has both intrinsic and instrumental value for Indigenous Australian peoples, including Yawuru. To understand and enable self-determination, there is a need to first understand what it means to live well, to make decisions, to have autonomy over the lives that Indigenous men and women value at the grassroots level. While there are important efforts needed at the national and international level, this chapter echoes the argument that it is self-determination facilitated at the local level with Indigenous communities that will ensure that the effectiveness of UNDRIP flows across multiple sectors and levels, rather than being confined to being an instrument of rights within the political and legal sphere with minimal impact on the lives of Indigenous communities on the ground.

\section{Acknowledgements}

The authors would like to acknowledge that this work was undertaken on Yawuru country and extend their gratitude to all the Yawuru women and men who have generously given their time to share their ideas, views and thoughts for advancing the research, in particular the Yawuru Reference and Guidance Committee who have been a guiding compass to ensure the research is fit for purpose for community needs and aspirations. We would also like to acknowledge the Yawuru Wellbeing Survey 2015 team of research assistants without whom the findings in Table 5.2 would 
not be possible. The research received both financial and in-kind support from the following organisations to which the authors are very grateful: Centre for Aboriginal Economic Policy Research (The Australian National University), Kimberley Institute Limited, Bankwest Curtin Economics Centre, Nulungu Institute (University of Notre Dame), Nyamba Buru Yawuru, Nagula Jarndu, Bottles of Australia and Yawuru Prescribed Body Corporate.

\section{References}

Altman JC (2007). The Howard Government's Northern Territory Intervention: Are neo-paternalism and Indigenous development compatible? Topical Issue 16/2007, Centre for Aboriginal Economic Policy Research, The Australian National University, Canberra.

Altman J \& Hinkson M (2010). Culture crisis: Anthropology and politics in Aboriginal Australia, UNSW Press, Sydney.

Anaya J (2004). Indigenous peoples in international law, Oxford University Press, Oxford.

Andersen C (2014). Metis: Race, recognition and the struggle for indigenous peoplehood, University of British Columbia Press, Vancouver.

Behrendt L (2002). Unfinished business: Indigenous self-determination. Arena Magazine 58(April-May):24-7.

Boas T \& Gans-Morse J (2009). Neoliberalism: From new liberal philosophy to anti-liberal slogan. Studies in Comparative International Development 44(2):137-61, doi.org/10.1007/s12116-009-9040-5.

Corntassel J (2008). Toward sustainable self-determination: Rethinking the contemporary indigenous-rights discourse. Alternatives 33:105-32, doi.org/ 10.1177/030437540803300106.

Coulthard G (2014). Red skin, white masks: Rejecting the colonial politics of recognition, University of Minnesota Press, Minneapolis, doi.org/10.5749/ minnesota/9780816679645.001.0001.

Daes E (2000). Striving for self-determination for indigenous peoples. In Kly Y \& Kly D (eds), In pursuit of the right to self-determination, Clarity Press, Geneva. 
Davies W (2015). Spirits of neoliberalism: 'Competitiveness' and 'wellbeing' indicators as rival orders of worth. In Rottenburg R, Merry S, Park S \& Mugler J (eds), The world of indicators: The making of governmental knowledge through quantification, Cambridge Studies in Law and Society, Cambridge, doi.org/10.1017/CBO9781316091265.011.

Davis M (2013). Community control and the work of national Aboriginal community controlled health organisation: Putting meat on the bones of the UNDRIP. Indigenous Law Bulletin 8(7):11-14.

Durie M (2006). Measuring Māori wellbeing, New Zealand Treasury Guest Lecture Series, New Zealand Treasury, Wellington.

Ermine W (2007). The ethical space of engagement. Indigenous Law Journal 6(1):193-203.

Fraser N \& Honneth A (2003). Redistribution or recognition? A politicalphilosophical exchange, Verso, London.

Ganesharajah C (2009). Indigenous health and wellbeing: The importance of country. Native Title Research Report, Report No. 1/2009, Australian Institute of Aboriginal and Torres Strait Islander Studies, Canberra.

Greiner R, Larson S, Herr A, \& Bligh V (2005). Wellbeing of Nywaigi traditional owners: The contribution of country to wellbeing and the role of natural resource management. CSIRO Sustainable Ecosystems, Townsville.

Grieves V (2007). Indigenous wellbeing: A framework for governments' Aboriginal cultural heritage activities. Report prepared for the NSW Department of Environment and Conservation, Sydney.

Howard-Wagner D (2010). From state of denial to state of emergency: Governing Australian indigenous communities through the exception. In Fassin D \& Pandolfi M (eds), Contemporary states of emergency: The politics of military and humanitarian interventions, Zone Publishing, New York.

HREOC (Human Rights and Equal Opportunity Commission) (2002). Chapter 2: Self-determination-the freedom to 'live well'. HREOC Social Justice Report 2002, Australian Human Rights Commission.

Humpage L (2008). Relegitimating neoliberalism? Performance management and Indigenous affairs policy. Policy and Politics 36(3):413-29, doi.org/ 10.1332/030557308X313688. 
Jordan K, Bullock H \& Buchanan G (2010). Exploring the tensions between statistical equality and cultural difference in Indigenous wellbeing frameworks: A new expression of an enduring debate. Australian Journal of Social Issues 45(3):333-62, doi.org/10.1002/j.1839-4655.2010.tb00183.x.

Kukutai T \& Walter M (2015). Recognition and indigenising official statistics: Reflections from Aotearoa New Zealand and Australia. Statistical Journal of the IAOS 31:317-26, doi.org/10.3233/sji-150896.

Mantziaris C \& Martin D (2000). Native title corporations: A legal and anthropological analysis, Federation Press, Sydney.

McCubbin L, McCubbin H, Zhang W, Kehl L \& Strom I (2013). Relational wellbeing: An Indigenous perspective and measure. Family Relations 62:354-65, doi.org/10.1111/fare.12007.

McKenna V \& Anderson K (2011). Kimberley dreaming: Old Law, new waysfinding new meaning, Presentation to World Congress for Psychotherapy, Sydney, 24-28 August.

Mirowski P (2009). Postface: Defining neoliberalism. In Mirowski P \& Plehwe D (eds), The road from Mont Pelerin: The making of the neoliberal thought collective, Harvard University Press, Cambridge, Massachusetts, doi.org/ $10.4159 / 9780674054264$.

Murphy M (2014). Self-determination as a collective capability: The case of Indigenous peoples. Journal of Human Development and Capabilities: A Multidisciplinary Journal for People Centred Development 15:320-34, doi.org/10.1080/19452829.2013.878320.

Panzironi F (2007). Indigenous peoples' right to self-determination and development policy. PhD thesis, University of Sydney, NSW.

Pearson N (1997). The concept of Native Title at Common Law. Australian Humanities Review 5.

Peck J \& Tickell A (2002). Neoliberalizing space. Antipode 35(3):380-404, doi.org/10.1111/1467-8330.00247.

Rowse T (2012). Rethinking social justice: From 'peoples' to 'populations', Aboriginal Studies Press, Canberra.

Sanders W (2002). Towards an Indigenous order of Australian government: Rethinking self-determination as Indigenous affairs policy, Discussion Paper 230, Centre for Aboriginal Economic Policy Research, The Australian National University, Canberra. 
Sen A (1999). Development as freedom, Knopf Press, New York.

Taylor C (1992). The politics of recognition. In Guttmann A \& Taylor C (eds), Multiculturalism and the 'politics of recognition', Princeton University Press, Princeton.

Taylor J (2008). Indigenous peoples and indicators of well-being: Australian perspectives on United Nations global frameworks. Social Indicators Research 87(1):111-26, doi.org/10.1007/s11205-007-9161-z.

Venugopal R (2015). Neoliberalism as concept. Economy and Society 44(2):16587, doi.org/10.1080/03085147.2015.1013356.

Watene K (2016). Indigenous peoples and justice. In Watene K \& Drydyk J (eds), Theorising justice: Novel insights and future directions, Rowman and Littlefield International, London.

Webb J (2012). Indigenous peoples and the right to self-determination. Journal of Indigenous Policy, 13:75-102.

Yap M (2017). In pursuit of culturally relevant indicators of Indigenous wellbeing: Operationalising the Recognition space. PhD thesis, The Australian National University, Canberra.

Yap M \& Yu E (2016a). Operationalising the capability approach: Developing culturally relevant indicators of indigenous wellbeing-An Australian example. Oxford Development Studies 44(3):315-331, doi.org/10.1080/136 00818.2016.1178223.

Yap M \& Yu E (2016b). Community wellbeing from the ground up: A Yawuru example, Bankwest Curtin Economics Centre Research Report 3/16.

Yawuru RNTBC (2011). Walyjala-jala buru jayida jarringgun Nyamba Yawuru ngan-ga mirlimirli [Planning for the future: Yawuru cultural management plan], Pindan Printing Pty Ltd, Broome.

Yu P (2012). The power of data in Aboriginal hands, Topical Issue 4/2012, Centre for Aboriginal Economic Policy Research, The Australian National University, Canberra. 
This text is taken from The Neoliberal State, Recognition and Indigenous Rights: New paternalism to new imaginings, edited by Deirdre Howard-Wagner, Maria Bargh and Isabel AltamiranoJiménez, published 2018 by ANU Press, The Australian National University, Canberra, Australia.

doi.org/10.22459/CAEPR40.07.2018.05 